\title{
Feeding Habits of the Mangrove Sesarmid Crab Neosarmatium trispinosum (Crustacea) in the Ryukyu Islands, Japan
}

\author{
Md. Sirajul Islam ${ }^{1 *}$, Md. Younus Mia ${ }^{1}$, Sultan Mahmud ${ }^{2}$ and B.M. Mostafa Kamal ${ }^{3}$ \\ ${ }^{1}$ Deprtment of Environmental Science and Resource Management, Mawlana Bhashani Science and Technology \\ University, Santosh, Tangail-1902, Bangladesh. ${ }^{2}$ Chittagong Veterinary and Animal Sciences University, Zakir \\ Hossain Road, Khulshi, Chittagong-4202, Bangladesh. ${ }^{3}$ Fish Seed Multiplication Firm, Natore-6400, Bangladesh \\ *Corresponding author: E-mail: msislamtazu@yahoo.com
}

\begin{abstract}
Sesarmid crabs are reported to dominate the Indo West-Pacific mangroves and consume huge amounts of mangrove leaves and detritus. Neosarmatium trispinosum Davie (1994) is common in the landward mangroves of the Ryukyu Islands in southern Japan. Stomach contents of the crabs collected from Okinawa, Miyako and Iriomote Islands showed that their diet consisted of mainly mangrove leaves with small amounts of sediments indicating that $N$. trispinosum is primarily detritivorous. The feeding preference of $N$. trispinosum was investigated by offering three types (green, yellow and brown) of Bruguiera gymnorrhiza leaves. Crabs were found to prefer brown leaves than the green or yellow ones. Consumption rate of brown leaves was significantly higher $(p<0.0001)$ in cases where green, yellow and brown leaves were provided together, than when provided separately. The $\mathrm{C} / \mathrm{N}$ ratio shows that the burrow sediments had $\mathrm{C} / \mathrm{N}$ ratios $2 / 3$ times lower than that of leaves, indicating that mangrove sediments could have higher nutritional value than mangrove leaves.
\end{abstract}

Keywords: Neosarmatium trispinosum, feeding habit, mangrove leaves, sediment, C/N ratio

\section{Introduction}

The sesarmid crabs are abundant in the mangroves and they affect soil chemistry and primary productivity (Smith et al., 1991), mangrove zonation and colonization, food web dynamics (Camilleri, 1992), nutrient retention, litter decomposition, and offshore export of mangrove production (Skov and Hartnoll, 2002). Although most grapsoids are opportunistic scavengers, many are essentially detritivorous as they feed on dead leaves that have fallen off the mangrove, particularly members of the family Sesarmidae, which are important components of mangrove ecosystems in the Indo-West Pacific, the African, the Caribbean and the South American coasts (Sheaves and Molony, 2000). About fifty species of sesarmid crabs have been reported to be predominantly associated with mangrove ecosystems (Islam et al., 2002).

The Neosarmatium, a sesarmid genus is widely distributed over the Indo-West Pacific region (Davie, 1994) and appears to be responsible for consuming a large percentage of the annual leaf fall of mangrove forests (Smith et al., 1991). Neosarmatium trispinosum Davie (1994) is limited to freshened areas of the river mouths, found in the mangrove swamps, in mud flats between low and high tide marks and in mangrove forests of the southern Ryukyu Islands of Japan (Islam et al., 2004). The crab emerges from its burrow at night to feed on leaf litter on the mud surface. It is a major leaf litter consumer, carrying leaves into its burrow where they are 
allowed to age and decay prior to consumption. This species is known from China, Japan, the Philippines, Thailand, Indonesia, Fiji, New Caledonia, New Guinea, the East Coast of Australia, Madagascar and the East and South Coasts of Africa (Davie, 1994).

Stomach contents are the primary means of verifying the natural diets of many crustaceans that feed on macroscopic food, although the mouthparts and gastric mills of the crabs generally reduce the food to small fragments (Robertson and Daniel, 1989). In many cases, absolute or relative quantities of food ingested are difficult to measure, and the type of food is difficult to identify (Smith et al., 1991). Multiple field and laboratory studies leave no doubt that sesarmids ingest mangrove leaves (Kwok and Lee, 1995; Twilley et al., 1997). Leaves often comprise more than $85 \%$ of sesarmid stomach contents (Dahdouh-Guebas et al., 1999), and they may remove 79 to $95 \%$ of mangrove leaf fall from the forest (Skov and Hartnoll, 2002). To date, the methods for stomach contents analysis of crustaceans have been poorly documented. Williams (1981) established a method for analyzing the natural diet of portunid crabs. Stomach contents of varunid and sesarmid crabs were analyzed by Mia et al. (2001) and Islam et al. (2002). Perhaps the easiest method is the frequency of occurrence method. It involves examination of stomach contents visually or with a microscope to sort out and identify the different food items in each stomach. This technique is rapid, and requires minimal equipment.

Freshly fallen mangrove leaves have notably high $\mathrm{C} / \mathrm{N}$ (Carbon/Nitrogen) ratios several times greater than 17, a value suggested as a general maximum for sustainable animal nutrition (Russel-Hunter, 1970; Wafar et al., 1997). Crabs might plaster leaves onto burrow walls to allow tannins to leach and increase the edibility of leaves (Giddins et al., 1986). In addition, leaf nitrogen $(\mathrm{N})$ content increases and $\mathrm{C} / \mathrm{N}$ ratio decreases during breakdown through microbial activity (Wafar et al., 1997). Thus by not eating leaves immediately but leaving them to age on the burrow wall did not only improve the digestibility but also decreased the $\mathrm{C} / \mathrm{N}$ ratio in their diet.

The aims of the present study were to determine the diet of the crabs through analyses of its stomach contents, the consumption rate of mangrove leaves, preference of different leaf types, $\mathrm{C} / \mathrm{N}$ ratios in leaves and sediments, and nutritional composition in the diet of $N$. trispinosum.

\section{Materials and Methods}

2.1. Study sites and experimental materials Non-gravid, healthy adults of Neosarmatium trispinosum and three types of leaves (green, yellow and brown) of the mangrove plant, Bruguiera gymnorrhiza were collected from three different mangroves of the Ryukyu Islands of southern Japan (Nuha river in Okinawa Island, Shimajiri swamp in Miyako island and Shira river in Iriomote island) between April 2002 and March 2003 to analyze stomach contents and to examine feeding habit and food preferences under laboratory condition. Leaves and sediments were collected from at least 10 to 15 burrows of $N$. trispinosum per station at Nuha and Shira river mangroves to analyze the $\mathrm{C} / \mathrm{N}$ ratios and nutritional composition in leaves and sediments, respectively.

\subsection{Stomach content analysis}

Crab samples ( $\mathrm{N}=10$ from each Islands) were randomly collected and fixed in $10 \%$ formalin solution immediately after collection and their stomach contents were analyzed within one month of sampling. Stomachs were carefully removed from each individual and the contents were washed with distilled water in a Petri dish. The quantity of ingested food was estimated visually according to the degree of fullness of the stomach and classified in 5 classes: $100 \%, 75 \%$, $50 \%, 25 \%$ and $0 \%$ full after Mizuno and Goze (1972). The percentage of fullness was calculated 
as follows: weight of stomach contents (full stomach weight - empty stomach weight), divided by body weight of the individual and multiplied by 100. A drop of the stomach contents was placed on a glass slide and examined under a binocular stereomicroscope (Nikon SMZ-10, x 25). Nature of the diet was determined using the percentage occurrence method of Williams (1981). The occurrence of each of the different food item in each stomach was recorded and results are expressed as the frequency of each item in the stomach. Stomach contents were scored for the following different food item categories: plant materials, animal materials, algae, silt/clay, and unidentified materials.

\subsection{Feeding behavior}

Leaf consumption: Crab samples $(\mathrm{N}=20$ for each leaf type) were housed separately for two days in ventilated plastic containers containing $100 \mathrm{ml}$ of brackish water (15\%o salinity) to acclimatize them to the laboratory condition. Each container was tilted slightly for the drainage of water. Green and yellow leaves were handpicked from the Bruguiera gymnorrhiza trees, while the brown ones were taken from the forest floor. Each crab received only a single type of leaf. Each leaf was weighed at the beginning of the experiment and daily to the nearest $0.001 \mathrm{~g}$ using an electronic balance. A new leaf of the same type was added to each container when less than $0.03 \mathrm{~g}$ of the previous leaf remained. All leaves were photocopied at the beginning of the experiment, so that the impact of feeding could be visualized. The carapace length (CL), carapace width (CW) and body weight (BW) of all the crabs was measured at the beginning of the experiment, and once a week to monitor growth. Water of all the containers was changed on alternate days. The experiment was conducted over a period of eight weeks. Leaf preference: The experimental individuals were provided with three types of leaves together as food to investigate leaf preference. Increase in body weight of the crabs and leaf consumption preferences were monitored regularly.

\section{4. $\mathrm{C} / \mathrm{N}$ ratios}

Leaves were rinsed with distilled water and dried in an oven at $60^{\circ} \mathrm{C}$ with air circulation for 2 days. Dried samples were ground with a mortar and pestle, and stored in a desiccators for analysis in a Shimadzu high-sensitivity C:N Analyzer (NC 80 model). For each sample, 3 replicates weighing $0.1 \mathrm{~g}$ each were placed in ceramic sample boats and ignited at $830^{\circ} \mathrm{C}$ for 1 minute. The connected Chromatopac recorder printed out the carbon (C) and nitrogen $(\mathrm{N})$ amounts as detected by the Sumigraph Detector. Sediments were washed with distilled water in plastic containers to remove salt, taking care not to lose any organic matter. After settling for 24 hours, the water was decanted and samples were oven dried at $60^{\circ} \mathrm{C}$ overnight. Dried samples were treated with dilute hydrochloric acid $(\mathrm{HCl}, 2 \mathrm{~N})$ overnight to remove carbonates and bicarbonates. Acid treated samples were oven dried again, and analysed as described above for the leaf samples.

\subsection{Nutritional composition}

To assess the nutritional composition, each type of leaf samples was analyzed in the Okinawa Environmental Technology Center, Japan. The amounts of energy, water, protein, fat, carbohydrate and ash in $100 \mathrm{~g}$ wet and dry samples were assessed. Water, ash, and fat content were assessed using a Drying Oven, Muffle Furnace and Soxhlet Extractor, respectively. Protein was analyzed using the Kjeldahl Method. The amount of carbohydrate and energy was estimated by the following equations: Carbohydrate $=100-($ Water + Ash + Fat + Protein $),$ Energy $=($ Protein $x 4)+($ Fat x 9$)+$ (Carbohydrate x 4).

\subsection{Statistical analysis}

Comparative data on stomach fullness, food consumption and growth rate, and $\mathrm{C} / \mathrm{N}$ ratios were analyzed using multiple analyses of variance (MANOVA) on the statistical package Stat View 5. A two-factor ANOVA was used to evaluate differences between sites and treatments of the experiments. Fisher's PLSD, Wilk's Lambda, Roy's Greatest Root, Hotelling-Lawley Trace and Pillai Trace indicated where there were 
significant differences in the means. Mean values are reported with $95 \%$ confidence intervals and $5 \%$ significance levels.

\section{Results and Discussion 3.1. Stomach contents}

Stomachs of Neosarmatium trispinosum were found to be almost full throughout the study period but the fullness (\%) was higher in winter than in summer and was always higher in males than in females, and also higher in crabs from Okinawa Island than those from the other two islands (Fig. 1). The diet of $N$. trispinosum consisted of mainly mangrove leaf fragments, complemented with some sediment materials (Fig. 2 ). The present findings agree with the findings of Skov and Hartnoll (2002), they further reported that the sesarmid crabs are major players in leaf degradation and nutrient regeneration in mangroves. The second most common item was clay or mud while relatively small amounts of animal matters were found in most of the individuals during both summer and winter seasons. The silt and clay materials found in the stomach might have been incidentally ingested with the leaf materials. The occurrence of more clay in the stomach during winter might be due to the fact that the crabs were found to remain in their burrows for extended periods in winter when they might have consumed clay to assuage their hunger. Several studies have noted that mangrove crabs may feed on mud (Kwok and Lee, 1995; Robertson, 1986). Skov and Hartnoll (2002) examined the feeding behavior of $N$. meinerti and $P$. (=Sesarma) guttatum and found that mud feeding clearly predominated.

The present observation of only a small amount of animal maters in the stomach contents was probably due to accidental consumption of small animals together with the leaves or when fallen leaves were insufficient in the crab surroundings. Dahdouh-Guebas et al. (1999) reported that Neosarmatium indicum and $N$. meinerti descended from their burrows above the high tide mark to feed on mangrove leaves which they took into their burrows. Giddins et al. (1986) noted that $N$. smithi took leaves into their burrows several weeks before consuming. During this time, tannins were lost from the leaves through leaching while nitrogen content increased through bacterial activity, resulting in improving quality of the food. The cause behind taking the leaves into the burrows is probably due to the more acceptable taste of aged leaves. Since $N$. trispinosum do not come outside their burrow during daytime, they must emerge during low tide at night and pull down leaf particles into burrows.

Unidentified materials were also found in the stomach contents in both the seasons. No significant differences were detected between summer and winter diets $(P>0.05$, Fisher's PLSD).

\subsection{Feeding behavior}

All the stocked crabs were found to survive on leaves of $B$. gymnorrhiza throughout the experimental period indicating that a diet of only green, yellow or brown leaves of B. gymnorrhiza was sufficient for their survival. However, the feeding preference was found to vary, green leaf were the least preferred leaf while the brown leave was the most preferred one (Fig. 3) and the crabs were found to grow fastest on brown leaves than the other two types of leaves $(P<0.0001$, Fisher's PLSD). When given alternatives, the crabs were found to prefer brown to yellow and then yellow to green leaves. The present findings agree with those of Islam et al. (2002). Giddins et al. (1986) reported that $N$. smithi consumed decayed leaves of Ceriops tagal much more than fresh and senescent leaves, which is consistent with the present findings. Micheli (1993) noted that Perisesarma messa and N. smithi did not exhibit a significant preference for newly fallen leaves of mangroves, and they consumed significantly more decayed leaves than senescent ones.

The average weekly consumption rate of brown leaves was higher than that of green or yellow leaves, as were weight changes $(P<0.0001$, Fisher's PLSD). This is probably due to the fact 
that the brown leaves were soft and were easier to tear by the crabs. Mia et al. (1999) reported that the consumption rate of brown leaves by Helice leachi was significantly higher than that of green and yellow leaves.

\section{3. $\mathrm{C} / \mathrm{N}$ ratios}

The $\mathrm{C} / \mathrm{N}$ ratio in sediment was found to be $2 / 3$ times lower than that of the leaves, indicating that sediments had higher nutritional value than the leaves. $\mathrm{C} / \mathrm{N}$ ratios in leaves taken from burrows in the Shira river were always higher (60.01) than those taken from the Nuha river (43.89) sites (Fig. $4)$. But the $\mathrm{C} / \mathrm{N}$ ratio in burrow sediments of the Nuha river was lower (20.76) than that of the Shira river (23.31) sites (Fig. 5). The present findings are similar to those of Tanzania, Kenya and Malaysia (Skov and Hartnoll 2002) but higher than those of Taiwan, Papua New Guinea, Brazil and India (Alongi et al. 1993) and lower than those of some north Australian mud (Boto and Wellington 1984). Skov and Hartnoll (2002) investigated the $\mathrm{C}$ and $\mathrm{N}$ contents and $\mathrm{C} / \mathrm{N}$ ratios of leaves in crab burrows and found that they do not differ significantly from those of freshly fallen leaves. The leaf-ageing hypothesis, that sesarmid crabs may plaster mangrove leaves to their burrow walls in order to improve leaf palatability and nutritional quality, has been an issue for discussion for more than 15 years (Giddins et al. 1986). Several papers, for instance, have noted how sesarmids in the field and in the laboratory may prefer to ingest aged leaves rather senescent leaves (Skov and Hartnoll 2002). The majority of studies have recorded $\mathrm{C} / \mathrm{N}$ ratios in mangrove leaves that far exceed the Russel-Hunter ratio of 17 . Leaves, in general, take a very long time to reach their lowest $\mathrm{C} / \mathrm{N}$ values, and in most cases the lowest $\mathrm{C} / \mathrm{N}$ ratios of decayed leaves are still at least double the Russel-Hunter ratio (Skov and Hartnoll 2002). However, significant differences $(\mathrm{P}<0.0001$, Fisher's PLSD) were found among $\mathrm{C}, \mathrm{N}$ and $\mathrm{TOM}$ contents and $\mathrm{C} / \mathrm{N}$ ratios of burrow leaves and sediments between the Nuha and the Shira River sites.

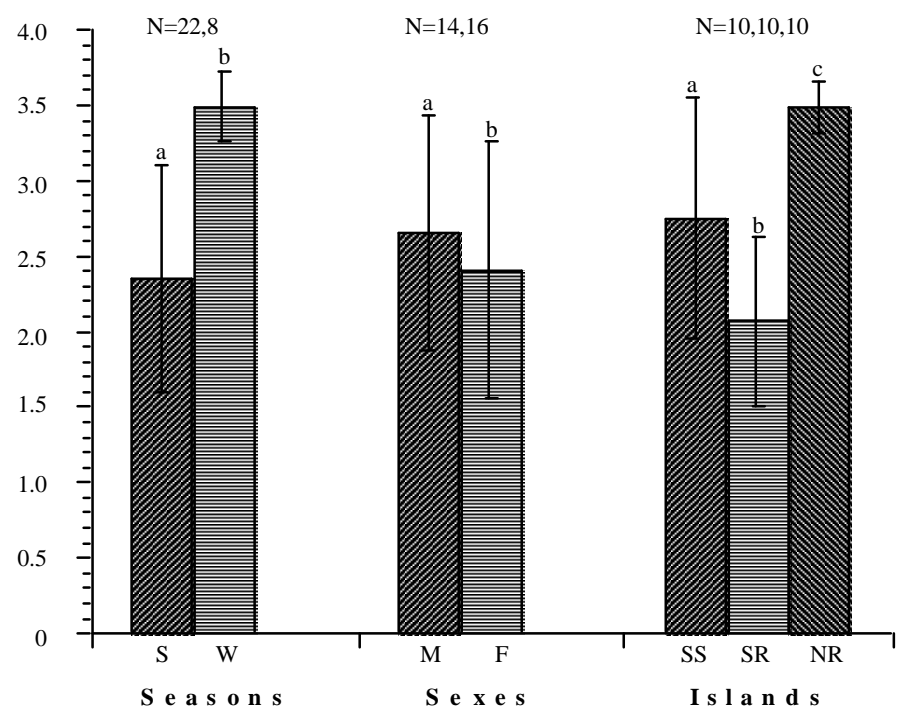

Fig. 1. Stomach fullness of Neosarmatium trispinosum. Data indicate mean $( \pm \mathrm{SD})$. Abbreviation: $\mathrm{S}$, summer; $\mathrm{W}$, winter; M, male; F, female; SS, Shimajiri swamp; SR, Shira River; NR, Nuha River. Bars with different letter are significantly different $(P<0.0001$, Stat view ANOVA, 5\% significance level). 

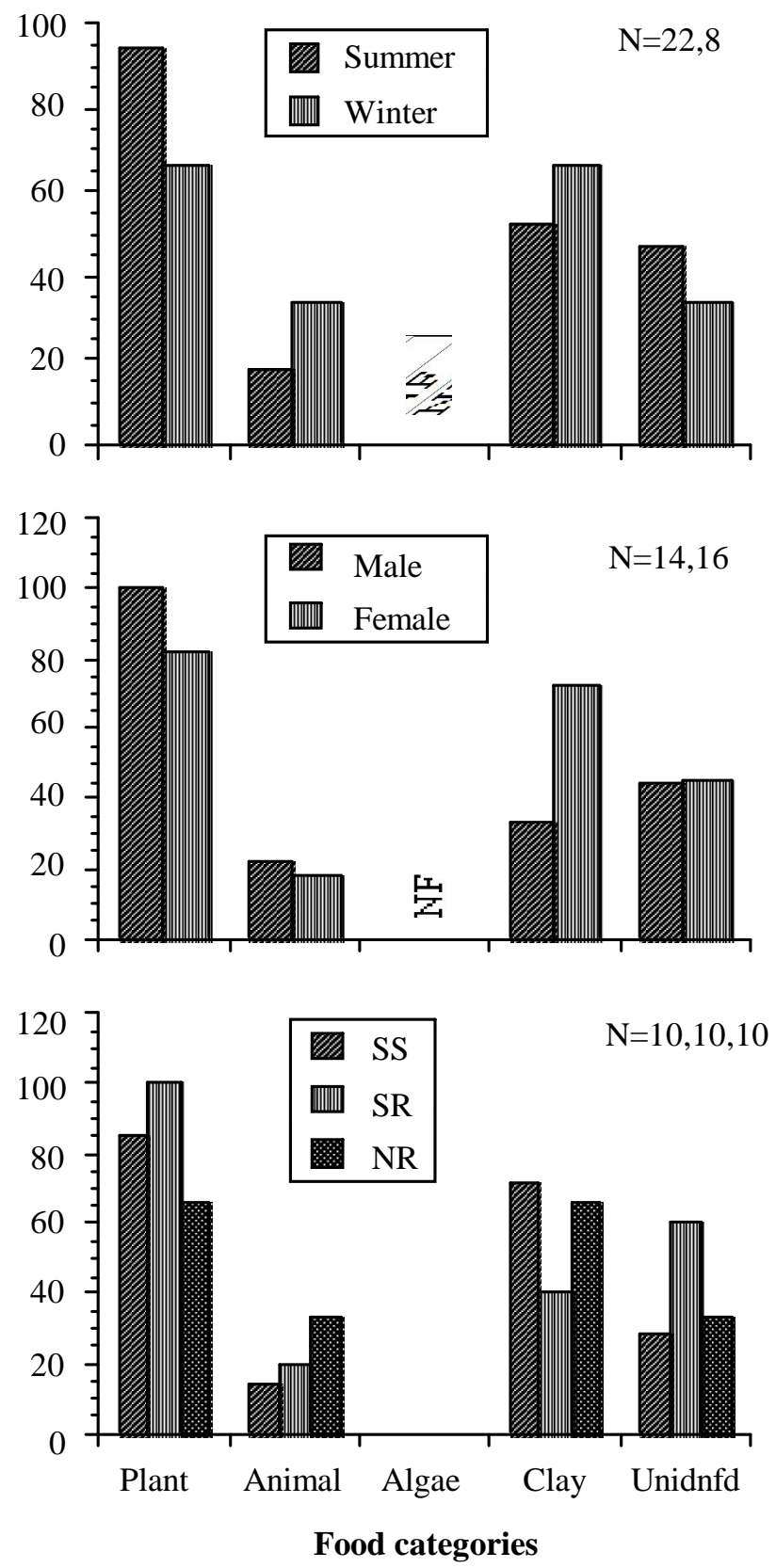

Fig. 2. Stomach contents of Neosarmatium trispinosum, collected from three different Islands. Abbreviation: NF, not found; SS, Shimajiri swamp; SR, Shira River; NR, Nuha River. 

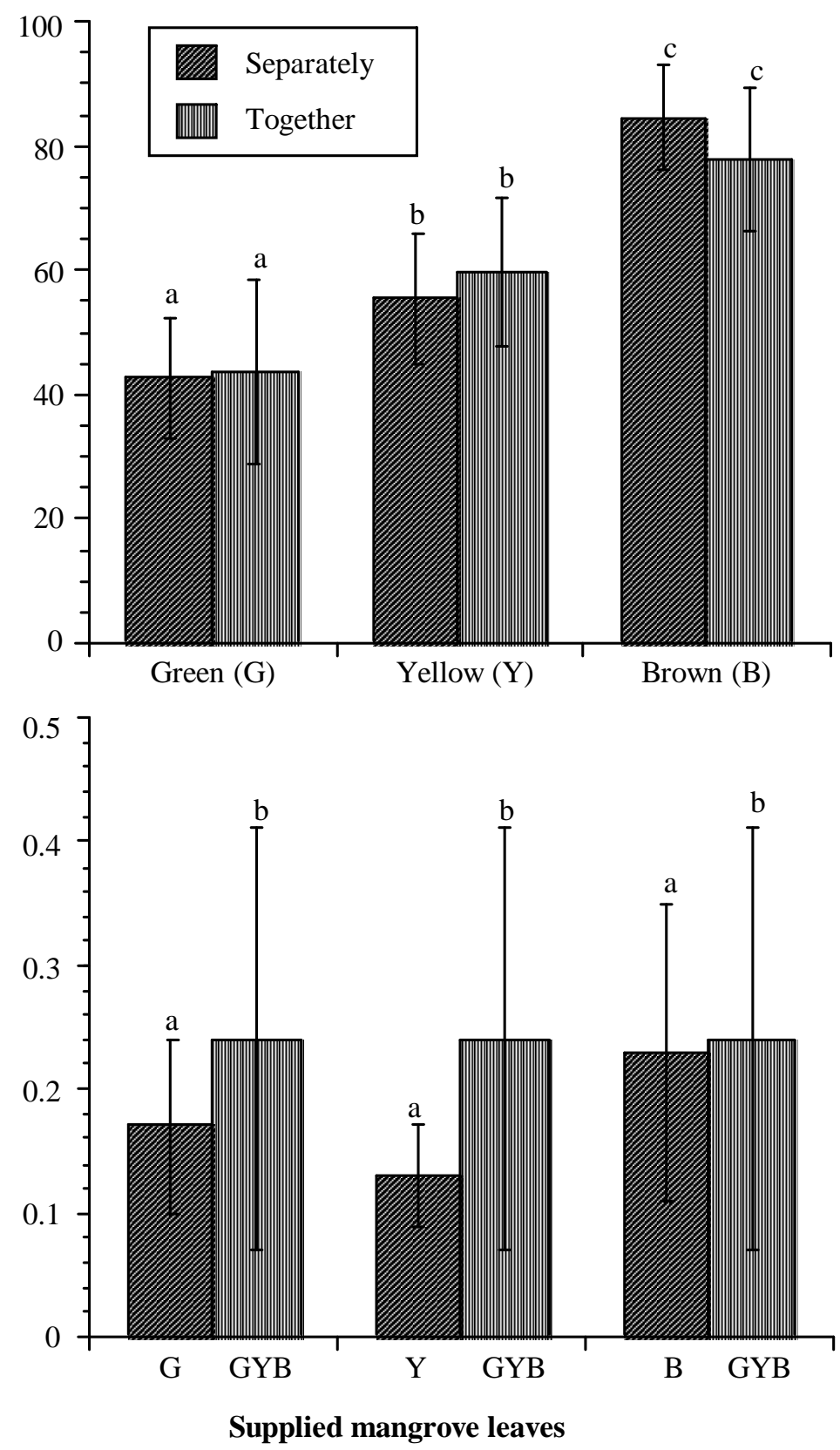

Fig. 3. Consumption and growth rate of Neosarmatium trispinosum, when three types of mangrove leaves were supplied separately and together. Data indicate mean $( \pm \mathrm{SD}), \mathrm{N}=24$. Bars with different letter are significantly different $(P<0.0001$, Fisher's PLSD, 5\% significance level). 

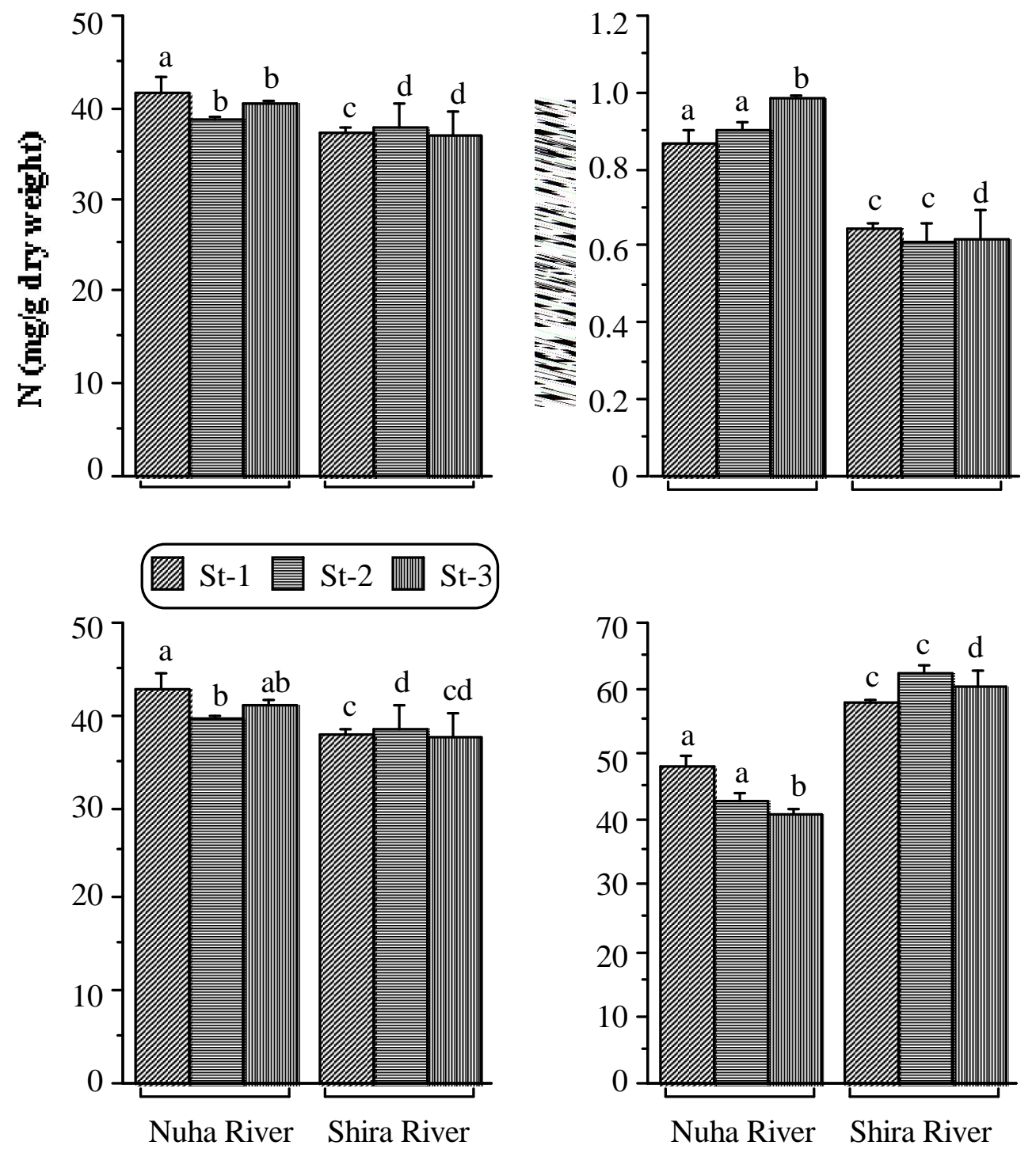

\section{Burrow leaves}

Fig. 4. Concentrations of $\mathrm{C}, \mathrm{N}$ and $\mathrm{TOM}$ contents, and $\mathrm{C} / \mathrm{N}$ ratios in burrow leaves of Neosarmatium trispinosum from two different mangroves. Data indicate mean $( \pm \mathrm{SE})$, error bars $=95 \%$ confidence interval, $\mathrm{N}=15$. Bars with different letter are significantly different ( $P<0.0001$, Fisher's PLSD, 5\% significance level). 

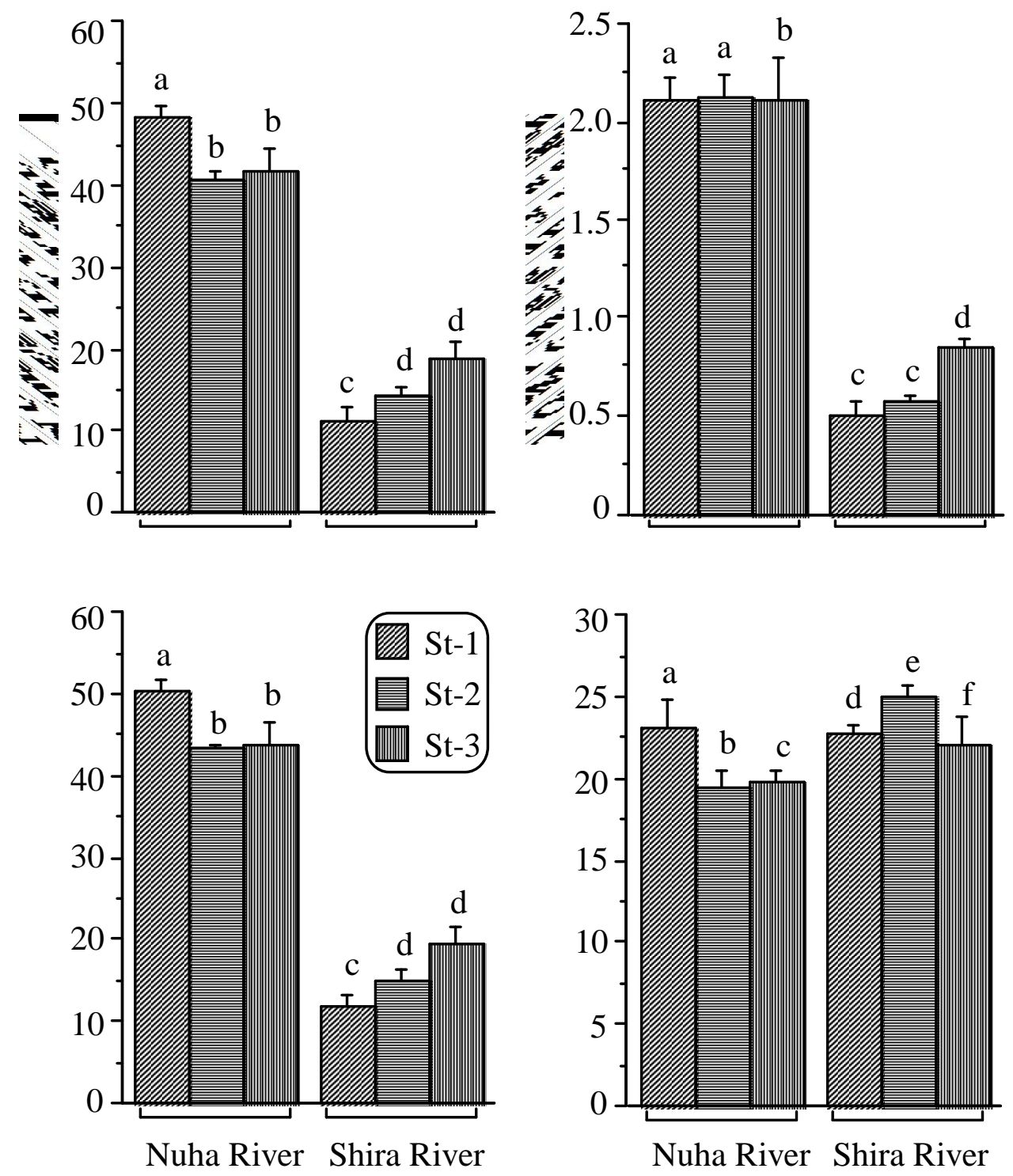

\section{Burrow sediments}

Fig. 5. Concentrations of $\mathrm{C}, \mathrm{N}$ and $\mathrm{TOM}$ contents, and $\mathrm{C} / \mathrm{N}$ ratios in burrow sediments of Neosarmatium trispinosum from two different mangroves. Data indicate mean $( \pm \mathrm{SE})$, error bars $=95 \%$ confidence interval, $\mathrm{N}=15$. Bars with different letter are significantly different $(P<0.0001$, Fisher's PLSD, 5\% significance level). 
Table 1. Nutritional content in $100 \mathrm{~g}$ green, yellow and brown leaves of Bruguiera gymnorrhiza on ww and dw basis.

\begin{tabular}{lllllll}
\hline Nutritional & \multicolumn{2}{l}{ Green leaves } & \multicolumn{2}{l}{ Yellow leaves } & \multicolumn{2}{l}{ Brown leaves } \\
\cline { 2 - 7 } composition & WW & DW & WW & DW & WW & DW \\
\hline Energy (k cal) & 91 & 317 & 98 & 328 & 118 & 339 \\
Water $(\mathrm{g})$ & 71.4 & - & 70.1 & - & 65.1 & - \\
Protein $(\mathrm{g})$ & 2.1 & 7.3 & 0.6 & 2.0 & 1.0 & 2.9 \\
Fat $(\mathrm{g})$ & 0.7 & 2.5 & 1.4 & 4.7 & 2.0 & 5.5 \\
Carbohydrate $(\mathrm{g})$ & 22.3 & 78.0 & 23.8 & 79.6 & 27.4 & 79.7 \\
Ash $(\mathrm{g})$ & 3.5 & 12.2 & 4.1 & 13.7 & 4.5 & 11.9 \\
\hline
\end{tabular}

Abbreviations: WW, wet weight; DW, dry weight. Samples collected from the habitat of N. trispinosum in the Shira River mangroves on Iriomote Island.

\subsection{Nutritional composition}

Dry leaves were more nutritious than wet leaves belonging to three different types (Table 1). The leaf material is originally high in carbohydrates, lipids and protein content (Bhosle et al., 1976). It is probably for this reason $N$. trispinosum consumed brown leaves more than the green or yellow leaves. Organic matter and nutrients are thus conserved in the forest rather than being washed out to the sea (Camilleri, 1989). Thus, $N$. trispinosum plays an important role in the energy flow pathway in the mangrove forest by providing food for detritus feeders both inside and outside the mangrove forest. Bacteria may certainly reach high densities in mangrove mud and are highly preferred by crabs (Alongi, 1988). The amount of carbohydrate and energy were always higher in brown leaves than the yellow or green leaves. Green leaves contained more protein than the other leaf types both in dry and in wet conditions (Table 1). The present findings agree with those of Islam et al. (2002).

\section{Acknowledgements}

We express our sincere thanks to Dr. Prosper L. Mfilinge (University of the Ryukyus, Japan), for his kind help to analyze the $\mathrm{C}, \mathrm{N}$ and TOM contents, and $\mathrm{C} / \mathrm{N}$ ratios in mangrove leaves and sediments. Sincere thanks are due to Prof. S. Shokita and Prof. T. Uehara (University of the Ryukyus, Japan), Prof. G. Paulay (University of Florida, USA) and Prof. C. P. Chen (Institute of Zoology, Taiwan) for reviewing this manuscript critically and for providing valuable suggestions to improve its quality. Sincere gratitude is also due to the JSPS (Japan Society for the Promotion of Science) for providing necessary financial support during conducting the remaining works of this study as well as for preparation, presentation and publication of the manuscript.

\section{References}

Alongi, D.M. 1988. Bacterial productivity and microbial biomass in tropical mangrove sediments. Microbiology and Ecology, 15: 59-79.

Alongi, D.M., Christoffersen, P. and Tirendi, F. 1993. The influence of forest type on microbial-nutrient relationships in tropical mangrove sediments. Journal of Experimental Marine Biology and Ecology, 171: 201-223.

Bhosle, N.B., Dhargalkar, V.K. and Matondkar, S.G.P. 1976. Biochemical composition of mangrove leaves from Goa. Indian Journal of Marine Sciences, 5: 239-241.

Boto, K.G. and Wellington, J.T. 1984. Soil characteristics and nutrient status in a northern Australian mangrove forest. Estuaries, 7: 61-69.

Camilleri, J. 1992. Leaf-litter processing by invertebrates in a mangrove forest in Queensland. Marine Biology, 114: 139-145.

Dahdouh-Guebas, F., Giuggioli, V., Olouch, A., Vannini, M. and Cannicci, S. 1999. Feeding habits of non-ocypodid crabs from two-mangrove forest in Kenya. Bulletin of 
Marine Science, 64: 291-297.

Davie, P.J.F. 1994. Revision of Neosarmatium serène and Soh (Crustacea: Brachyura: Sesarminae) with descriptions of two new species. Memoirs of the Queensland Museum, 35: 35-74.

Giddins, R.L., Lucas, J.S., Neilson, M.J. and Richards, G.N. 1986. Feeding ecology of the mangrove crab, Neosarmatium smithi (Crustacea: Decapoda: Sesarmidae). Marine Ecology Progress Series, 33: 147-155.

Islam, M.S., Shokita, S. and Salim, M. 2002. Feeding habits of the mangrove sesarmid crab Neosarmatium indicum (Crustacea: Decapoda: Brachyura: Sesarmidae) under laboratory conditions. Bulletin of the Faculty of Science, University of the Ryukyus, 74: 81-97.

Islam, M.S., Rahman, M.A. and Shokita, S. 2004. Larval development of the mangrove sesarmid crab Neosarmatium trispinosum (Brachyura: Grapsoidea) described from laboratory-reared material. Journal of Crustacean Biology, 24: 356-371.

Kwok, P.W. and S.Y. Lee. 1995. The growth performances of two mangrove crabs, Chiromanthes bidens and Parasesarma plicata, under different leaf litter diets. Hydrobiologia, 295: 141-148.

Mia, M.Y., Shokita, S., Kamizato, K. and Kinjo, M. 1999. Feeding habits of the grapsid crab, Helice leachi Hess, under laboratory conditions. Bulletin of the Faculty of Science, University of the Ryukyus, 68: 31-44.

Mia, M.Y., Shokita, S. and Watanabe, S. 2001. Stomach contents of two grapsid crabs, Helice formosensis and Helice leachi. Fisheries Science, 67: 173-175.

Micheli, F. 1993. Feeding ecology of mangrove crabs in northeastern Australia: mangrove litter consumption by Sesarma messa and Sesarma smithi. Journal of Experimental Marine Biology and Ecology, 171: 165-186.

Mizuno, N. and Goze. K. 1972. Ecology of
Riverine Animals, Tsukiji Shokan, Tokyo, Japan, 246 pp. (In Japanese with English summary).

Robertson, A.I. 1986. Leaf-burying crabs: their influence on energy flow and export from mixed mangrove forest (Rhizophora spp.) in northeastern Australia. Journal of Experimental Marine Biology and Ecology, 102: 237-248.

Robertson, A.I. and Daniel, P.A. 1989. The influence of crabs on litters processing in high inter-tidal mangrove forest in tropical Australia. Oecologia, 103: 640-646.

Russel-Hunter, W.D. 1970. Aquatic productivity: an introduction to some basic aspects of biological oceanography and limnology, Macmillan, New York.

Sheaves, M. and Molony, B. 2000. Short-circuit in the mangrove food chain. Marine Ecology Progress Series, 199: 97-109.

Skov. M.W. and Hartnoll, R.G. 2002. Paradoxical selective feeding on a low-nutrient diet: why do mangrove crabs eat leaves? Oecologia, 131: 1-7.

Smith, T.J., Boto, K.G.., Frusher, S.D. and Giddins, R.L. 1991. Keystone species and mangrove forest dynamics: the influence of burrowing by crabs on soil nutrient status and forest productivity. Estuarine, Coastal and Marine Science, 33: 419-432.

Twilley, R.R., Pozo, M., Garcia, V.H., Rivera-Monroy, V.H., Zambrano, R. and Bodero, A. 1997. Litter dynamics in riverine mangrove forests in the Guayas River estuary, Ecuador. Oecologia, 111: 109-122.

Wafar, S., Untwale, A.G. and Wafar, M. 1997. Litter fall and energy flux in a mangrove ecosystem. Estuarine, Coastal and Shelf Science, 44: 111-124.

Williams, M.J. 1981. Methods for analysis of natural diet in portunid crabs (Crustacea: Decapoda: Portunidae). Journal of Experimental Marine Biology and Ecology, 52: 103-113. 
